\title{
Editorial
}

\section{Special Issue on the Environmental Fate of Emerging Organic Micro-Contaminants}

\author{
John Wilkinson ${ }^{1}\left[\right.$ and Peter S. Hooda ${ }^{2, *}$ \\ 1 Environment and Geography Department, University of York, York YO10 5NG, UK \\ 2 Faculty of Science, Engineering and Computing-Kingston University, Kingston-upon-Thames KT1 2EE, UK \\ * Correspondence: p.hooda@kingston.ac.uk
}

Received: 19 July 2019; Accepted: 24 July 2019; Published: 26 July 2019

\section{Introduction}

The toxicity and fate of pharmaceuticals and other emerging micro-organic contaminants in the natural and built environments have been the focus of much research over the last 20 years [1,2]. Recently, particular focus has been centred on the fate of antimicrobial chemicals, including antibiotics and antifungals, as well as other medicinal and anthropogenic chemicals [3]. The occurrence of such contaminants in the environment is thought to contribute to adverse outcomes, including the selection of antimicrobial resistance [4] and endocrine disruption in exposed non-target organisms [5]. Much work is needed to elucidate the environmental fate of micro-organic contaminants, particularly related to their removal from sewage effluents and their potential uptake into both aquatic and terrestrial foodstuffs [2]. Underpinning such work is the need for innovative and robust analytical methodologies for the quantification of these contaminants in a broad range of environmental matrices.

\section{Micro-Organic Contaminants: Perspectives on Detection, Effects and Removal/Treatment}

This Special Issue (SI) brings together a broad range of recent advances in the field of micro-organics, ranging from medicinal contaminants to industrial chemicals in the environment. Notably, these range from chemical extraction and large-scale analysis to adverse effects on non-target aquatic organisms and potential risk to humans via contaminated foodstuffs. Additionally, this Special Issue presents novel contaminant treatment and degradation methods of both physical and biological natures. A total of nine articles were selected for publication.

The first article, authored by Svahn and Björklund, presents an innovative and widely accessible methodology by which pharmaceuticals can be extracted from complex environmental matrices using a household espresso machine [6]. Such advancements have the potential to increase accessibility to environmental research, which is dominated by the use of complex and often prohibitively expensive equipment. As such, access to technology, such as the highly sensitive mass spectrometers needed to quantify micro-organic contaminants, tends to disproportionally favour wealthy countries (e.g., Western Europe, North America and China) [7] and institutions. The second article of this SI, authored by Wilkinson et al., presents an innovative methodology by which access to such analytical equipment may be achieved [7]. The authors accomplish this via affordable, validated and scientifically robust means for quantification of a broad suite of antimicrobials and other common medicinal products in a worldwide water enabling study [7].

With the capability and means to extract and quantify micro-organic contaminants, the study of the concomitant biological effects they may elicit in exposed organisms was also a focus of this SI. The selection of resistance to antimicrobial medicines is of increasing concern to the scientific community. In the third article of this SI, Osińska et al. demonstrate that the occurrence of antimicrobial-resistant genes to beta-lactams and tetracyclines is frequently detected and poorly, if at all, removed in wastewater 
treatment plants [8]. Similarly, the authors of the fourth article in this SI, Park et al., found that contaminants commonly detected in wastewater (plasticisers and a biocide) manipulate the expression of the egg yolk protein vitellogenin in a compound and dose-specific manner [9]. Studies elucidating the potential biological impacts of micro-organic contaminants were not limited to lower organisms in this SI. The fifth article presents a human health risk assessment for secondary exposure to veterinary medicines via consumption of contaminated shrimp [10]. Tsai et al. conclude that while some aqua-farmed shrimp in Taiwan do bioaccumulate detectable concentrations of antimicrobials, the risk to humans consuming them is negligible.

Ultimately, to reduce the risk of biological disruption on any level, removal or degradation of micro-organic contaminants is key. In total, four articles in this SI relate to various approaches to degrading or removing micro-organic contaminants. The sixth article of this SI, authored by Lee et al., establishes that the types of perfluoro-alkyl contaminants entering wastewater treatment are linked to the type of local industry, and their removal is most effective via a combination of oxidation and activated carbon adsorption [11]. Similarly, the seventh article, authored by Baresel et al., reinforces the finding that adsorption of some micro-organic contaminants is an effective means to separate them from wastewater effluent prior to discharge into the environment [12]. In addition to physical separation/degradation, the last two articles of this SI focus on biological removal of such contaminants. Specifically, Zhang et al. demonstrate effective and rapid degradation of a common industrial contaminant using the Gram-positive bacterium Rhodococcus sp. [13]. This significant finding raises the potential for this bacterium to be used for targeted remediation in the environment or for treatment of industrial wastes [13]. Similarly, the last article of this SI, authored by Bai et al., shows effective decolorization of various dyes by the Gram-negative bacterium Pseudomonas putida, again indicating the potential of biological treatments in the breakdown of micro-organic contaminants [14].

\section{Perspectives on the Future of Research on Micro-Organic Contaminants in the Environment}

While the work presented in this SI offers concrete advancements to the study of anthropogenic contaminants in the environment, much work is still needed. In future years, it can be anticipated that increasing water scarcity in light of global climate change and increasing urbanisation of the global population will stress existing resources for clean freshwater. With this stress may come increasing contamination of water. Furthermore, little is currently known about the occurrence of micro-organic pollutants in much of the developing world. Effective means of risk-based prioritisation of contaminants, particularly in foodstuffs and bathing and drinking water, are needed within this context. Ultimately, much additional work is needed to identify affordable and effective means by which to remove these contaminants from water.

\section{References}

1. Wilkinson, J.L.; Hooda, P.S.; Barker, J.; Barton, S.; Swinden, J. Ecotoxic pharmaceuticals, personal care products, and other emerging contaminants: A review of environmental, receptor-mediated, developmental, and epigenetic toxicity with discussion of proposed toxicity to humans. Crit. Rev. Environ. Sci. Technol. 2016, 46, 336-381. [CrossRef]

2. Wilkinson, J.; Hooda, P.S.; Barker, J.; Barton, S.; Swinden, J. Occurrence, fate and transformation of emerging contaminants in water: An overarching review of the field. Environ. Pollut. 2017, 231, 954-970. [CrossRef]

3. Shao, S.; Hu, Y.; Cheng, J.; Chen, Y. Research progress on distribution, migration, transformation of antibiotics and antibiotic resistance genes (ARGs) in aquatic environment. Crit. Rev. Biotechnol. 2018, 38, 1195-1208. [CrossRef] [PubMed]

4. Tell, J.; Caldwell, D.J.; Häner, A.; Hellstern, J.; Hoeger, B.; Journel, R.; Mastrocco, F.; Ryan, J.J.; Snape, J.; Straub, J.O.; et al. Science-based targets for antibiotics in receiving waters from pharmaceutical manufacturing operations. Integr. Environ. Assess. Manag. 2019, 15, 312-319. [CrossRef] [PubMed]

5. Windsor, F.M.; Ormerod, S.J.; Tyler, C.R. Endocrine disruption in aquatic systems: Up-scaling research to address ecological consequences. Biol. Rev. 2018, 93, 626-641. [CrossRef] [PubMed] 
6. Svahn, O.; Björklund, E. Extraction Efficiency of a Commercial Espresso Machine Compared to a Stainless-Steel Column Pressurized Hot Water Extraction (PHWE) System for the Determination of 23 Pharmaceuticals, Antibiotics and Hormones in Sewage Sludge. Appl. Sci. 2019, 9, 1509. [CrossRef]

7. Wilkinson, J.L.; Boxall, A.; Kolpin, D.W. A novel method to characterise levels of pharmaceutical pollution in large-scale aquatic monitoring campaigns. Appl. Sci. 2019, 9, 1368. [CrossRef]

8. Osińska, A.; Korzeniewska, E.; Harnisz, M.; Niestępski, S. Quantitative Occurrence of Antibiotic Resistance Genes among Bacterial Populations from Wastewater Treatment Plants Using Activated Sludge. Appl. Sci. 2019, 9, 387.

9. Park, K.; Jo, H.; Kim, D.K.; Kwak, I.S. Environmental Pollutants Impair Transcriptional Regulation of the Vitellogenin Gene in the Burrowing Mud Crab (Macrophthalmus Japonicus). Appl. Sci. 2019, 9, 1401. [CrossRef]

10. Tsai, M.Y.; Lin, C.F.; Yang, W.C.; Lin, C.T.; Hung, K.H.; Chang, G.R. Health Risk Assessment of Banned Veterinary Drugs and Quinolone Residues in Shrimp through Liquid Chromatography-Tandem Mass Spectrometry. Appl. Sci. 2019, 9, 2463. [CrossRef]

11. Lee, S.H.; Cho, Y.J.; Lee, M.; Lee, B.D. Detection and Treatment Methods for Perfluorinated Compounds in Wastewater Treatment Plants. Appl. Sci. 2019, 9, 2500. [CrossRef]

12. Baresel, C.; Harding, M.; Fång, J. Ultrafiltration/Granulated Active Carbon-Biofilter: Efficient Removal of a Broad Range of Micropollutants. Appl. Sci. 2019, 9, 710. [CrossRef]

13. Zhang, Y.; Ji, J.; Xu, S.; Wang, H.; Shen, B.; He, J.; Qiu, J.; Chen, Q. Biodegradation of Picolinic Acid by Rhodococcus sp. PA18. Appl. Sci. 2019, 9, 1006. [CrossRef]

14. Bai, Z.; Sun, X.; Yu, X.; Li, L. Chitosan Microbeads as Supporter for Pseudomonas putida with Surface Displayed Laccases for Decolorization of Synthetic Dyes. Appl. Sci. 2019, 9, 138. [CrossRef]

(C) 2019 by the authors. Licensee MDPI, Basel, Switzerland. This article is an open access article distributed under the terms and conditions of the Creative Commons Attribution (CC BY) license (http://creativecommons.org/licenses/by/4.0/). 